\title{
Status Ekonomi Orang Tua dengan Motivasi Belajar Siswa
}

\author{
Nayla Andreasari ${ }^{1}$, Aspin $^{2}$, \& Sitti Mikarna Kaimuddin ${ }^{3}$ \\ Jurusan Psikologi \\ Fakultas Keguruan dan Ilmu Pendidikan, Universitas Halu Oleo \\ andreasarinayla@gmail.com¹,aspin.psi@gmail.com²,smikarnak@uho.ac.id²
}

\begin{abstract}
Abstrak : Motivasi dan belajar merupakan dua hal yang tidak dapat dipisahkan, karena dengan motivasi, siswa akan semangat dalam proses belajar. Motivasi terbagi atas dua yaitu intrinsik dan ekstrinsik. Motivasi ekstrinsik mencakup keluarga. Status ekonomi orang tua dapat mempengaruhi motivasi belajar; Penelitian ini bertujuan untuk mengetahui apakah terdapat hubungan antara status ekonomi orang tua dengan motivasi belajar siswa SD Negeri Matabaho dan SD Negeri 7 Langara Kecamatan Wawonii Barat; Jenis penelitian ini adalah kuantitatif dengan desain korelasional. Populasi dalam penelitian ini sebanyak 106 orang siswa yang terdiri dari kelas IV sampai dengan kelas VI. Teknik penarikan sampel dalam penelitian ini menggunakan Purposive Total Sampling sehingga ditemukan sampel sebanyak 89 orang siswa ; Pengumpulan data dilakukan dengan menggunakan skala status ekonomi orang tua dan skala motivasi belajar; Teknik analisis data menggunakan formula korelasi Product Moment Pearson dengan menggunakan Statistical Product and Service Solution (SPSS) 20.0; Berdasarkan hasil analisis data, ditemukan nilai signifikansi sebesar 0,510 yang artinya tidak ada hubungan antara status ekonomi orang tua dengan motivasi belajar siswa SD Negeri Matabaho dan SD Negeri 7 Langara Kematan Wawonii Barat.
\end{abstract}

Kata kunci : motivasi belajar ; orang tua ; status ekonomi

Abstract : Motivation and learning are two inseparable things, with motivation, students will be enthusiastic in the learning process. Motivation is divided into two, namely intrinsic and extrinsic. Extrinsic motivation includes family. The economic status of parents can influence student's motivation to learn; This study aimed to determining whether there is a relationship between the economic status of parents and the students' learning motivation at SD Negeri Matabaho and SD Negeri 7 Langara, Wawonii Barat District; This study is a quantitative with a correlational design. The population in this study are 106 students consisting of class IV to class VI. The sampling technique used in this study is purposive total sampling until 89 students are found as samples; The data are collected using a scale of the economic status of parents and a scale of learning motivation; The data analysis technique uses the Pearson Product Moment correlation formula with Statistical Product and Service Solution (SPSS) 20.0; Based on the results of data analysis, it is found that the significance value is 0.510, which means that there is no relationship between the economic status of parents and the learning motivation of SD Negeri Matabaho and SD Negeri 7 Langara Kematan Wawonii Barat.

Keywords : learning motivation ; parents ; economic status 


\section{Pendahuluan}

Menurut Sumarna, Syafe'i \& Marwah (2018) pendidikan merupakan hal yang amat penting bagi manusia dalam segala aspek kehidupannya. Sedangkan menurut Nurkholis (2018) pendidikan juga merupakan sebuah aktivitas yang memiliki maksud atau tujuan tertentu yang diarahkan untuk mengembangkan potensi yang dimiliki manusia sebagai manusia atau sebagai masyarakat dengan sepenuhnya.

Berdasarkan undang-undang tahun 2003 Nomor 20 tentang Sistem Pendidikan Nasional (dalam Kadir, Fauziah, Yulianto, Baehaki, Kurnianto, Rosmianti \& Nu'man, 2012) menegaskan bahwa pendidikan adalah usaha sadar dan terencana untuk mewujudkan suasana belajar dan proses pembelajaran agar peserta didik secara aktif mengembangkan potensi dirinya. Selain itu, pendidikan merupakan suatu rangkaian psiko-fisik untuk menuju ke perkembangan pribadi manusia seutuhnya, yang berarti menyangkut ranah kognitif, afektif, dan psikomotorik.

Hakikatnya seseorang menempuh pendidikan bertujuan untuk memperoleh ilmu pengetahuan. Selain itu, tujuan seseorang menempuh pendidikan secara luas adalah untuk meningkatkan derajat, martabat dan kesejahteraan bagi dirinya dan keluarganya.

Menurut Uno (2011) dalam menyelenggarakan pendidikan terdapat dua faktor yang mempengaruhi proses pendidikan dan ketercapaiannya tujuan pendidikan. Faktor-faktor tersebut adalah faktor internal yang meliputi harapan akan cita-cita, keinginan untuk berhasil, serta dorongan kebutuhan untuk belajar, dan faktor eksternal yang meliputi adanya penghargaan, lingkungan belajar yang kondusif, serta kegiatan belajar yang menarik.

Cita-cita dan keinginan untuk berhasil merupakan tujuan dari seorang individu dalam pendidikan. Oleh karena itu, seseorang membutuhkan motivasi atau energi serta dorongan yang secara sadar atau tidak sadar, baik yang bersumber dari dalam diri individu itu sendiri maupun dari luar individu untuk mengawali suatu kegiatan yang dapat mewujudkan citacitanya tersebut, salah satunya yaitu belajar.

Proses pembelajaran siswa akan berhasil jika siswa mempunyai motivasi dalam belajar. Oleh karena itu, guru perlu menumbuhkan motivasi belajar pada siswa (Suprihatin 2015). Menurut Fauzia, Rosnaningsih, dan Azhar (2017) motivasi merupakan dorongan seseorang secara sadar atau tidak sadar untuk melakukan sesuatu kegiatan untuk mencapai tujuannya. Motivasi juga bisa berasal dari dalam diri dan juga dari orang lain, baik itu guru, keluarga dan juga teman. Siswa yang memilki motivasi belajar maka akan serius dan tertarik dalam pembelajaran sehingga siswa mendapatkan hasil yang memuaskan, tetapi siswa yang tidak memiliki motivasi belajar maka akan selalu merasa bosan dalam pembelajaran.

Menurut Dimyati (dalam Kompri 2015) dalam motivasi ada empat unsur yang mempengaruhi belajar yakni cita-cita dan aspirasi siswa, kemampuan siswa, kondisi siswa, dan kondisi lingkungan siswa. Kondisi lingkungan siswa meliputi kondisi lingkungan sekolah, pergaulan teman sebaya, lingkungan tempat tinggal, lingkungan keluarga serta status ekonomi orang tua.

Lilawati (2020) peran orang tua adalah menjadi orang tua yang dapat memotivasi anaknya dalam segala hal, termaksud memotivasi meraka dalah hal belajar. Sehingga orang tua memiliki kewajiban untuk menyediakan segala kebutuhan lahir dan batin terkait dengan pendidikan anak, dimana orang tua sebagai pendorong perkembangan pengetahuan individu dipengaruhi oleh interaksi sosialnya dan status ekonominya. Orang tua sangat memegang peranan penting 
dalam memberikan motivasi belajar kepada anak terutama ditekankan pada pengetahuan dan pengalaman yang pernah diterima orang tuanya. Namun tidak hanya berpusat pada tingkat pendidikan orang tua, jenjang status ekonomi keluarga juga ikut mempengaruhi (Gebrinna, Dahlan \& Andrianto 2019).

Bramanhta \& Yulianto (2020) Terkadang orang tua yang keadaan ekonominya rendah beranggapan bahwa sekolah bagi anaknya hanya agar anaknya bias membaca dan menulis sehingga tidak perlu anaknya pandai dan menyekolahkan putra dan putrinya sampai ke jenjang yang lebih tinggi karena nanti hanya akan meneruskan pekerjaan orang tuanya. Hal ini yang menyebabkan siswa yang keadaan ekonomi orang tuanya rendah bersekolah hanya dijadikan sebagai rutinitas. Dalam bersekolah mereka tidak mempunyai motivasi yang lebih karena bersekolah hanya agar mereka bisa membaca dan menulis. Sebaliknya menurut Prabawa (2014) apabila perekenomian cukup, lingkungan yang dihadapi individu itu lebih luas, maka dapat mempunyai kesempatan yang luas pula untuk mengembangkan kemampuan dan kecakapannya. Tetapi, jika perekonomian orang tua itu kurang, belum tentu juga individu mengalami kesulitan dan tidak akan mendapatkan kesempatan yang luas untuk mengembangkan kemampuan dan kecakapannya.

Status ekonomi orang tua sangat berpengaruh dalam memenuhi kebutuhan hidup keluarga. Orang tua yang memiliki status ekonomi baik cenderung lebih mudah mencukupi kebutuhan hidup keluarganya, sehingga dengan tercukupinya kebutuhan hidup maka akan memudahkan orang tua memfasilitasi anaknya untuk menempuh pendidikan dengan harapan anak akan mampu mengembangkan kemampuan dan kecakapannya serta mencapai cita-cita yang diinginkan.

$$
\text { Selain berpengaruh pada }
$$
pemenuhan kebutuhan keluarga, kondisi status ekonomi juga akan berpengaruh pada kondisi pendidikan individu, dimana menurut Widodo, Ani \& Chotimah (2017) pendidikan yang baik dapat dinikmati oleh anak apabila orang tua peduli pada masa depan anaknya. Pratiwi \& Prasetya, (2019) menambahkan jika status ekonomi orang tua tinggi, orang tua dapat menyediakan kebutuhan anaknya baik kebutuhan primer maupun kebutuhan sekunder. Menurut Badan Pusat Statistik, pada tahun 2020 jumlah penduduk miskin di Kabupaten Konawe Kepulauan sebanyak 1.748 ribu jiwa.

Menurut Kartono (2006) status ekonomi merupakan derajat keluarga atau seseorang di lingkungan masyarakat berdasarkan status ekonomi maupun pendapatan perbulan. Sedangkan menurut Sugihartono (dalam Utomo, Adi \& Sunarto 2018) status ekonomi orang tua meliputi tingkat pendidikan orang tua, pekerjaan orang tua, dan penghasilan orang tua. Slameto (dalam Rizkiana, 2014) menjelaskan bahwa kondisi ekonomi keluarga memiliki kaitan yang kuat dengan motivasi belajar anak sehingga menghasilkan proses belajar anak yang meningkat. Kebutuhan-kebutuhan anak yang harus dipenuhi adalah makanan, pakaian, kesehatan dan fasilitas-fasilitas belajar yang lain seperti ruang belajar atau kelas, meja, kursi, papan tulis, buku-buku maupun yang lainnya.

Daerah Kecamatan Wawonii Barat merupakan wilayah yang tergolong daerah pedesaan dan termasuk daerah kawasan pertanian dan nelayan. Menurut data Badan Pusat Statistik Kecamatan Wawonii Barat tahun 2018/2019 yang menggambarkan wilayah Kecamatan Wawonii Barat yang terdiri dari 16 desa dan persentase lahan pertanian sebesar $50 \%$ dari total keseluruhan wilayah, sesuai dengan data tersebut. Masyarakat di wilayah kecamatan Wawonii Barat mayoritas bekerja sebagai petani, nelayan, sehingga penghasilan yang dihasilkan dari pekerjaan tersebut masih berada pada taraf rendah. 
Berikut ini merupakan data-data awal status ekonomi orang tua yang diperoleh peneliti dari SD Negeri Matabaho dan SD Negeri 7 Langara Kecamatan Wawonii barat, antara lain sebagai berikut. Tabel (1) Tingkat status ekonomi orang tua siswa terbagi atas dua yaitu ekonomi tinggi dan rendah. Tabel (2) Jenis pekerjaan orang tua siswa terdiri dari PNS, pedagang, wiraswasta, ibu rumah tangga, petani dan nelayan. Tabel (3) Penghasilan orang tua siswa berkisar dari Rp 0 sampai dengan $\mathrm{Rp}$ 5.000.000.

Tabel di bawah menujukkan bahwa status ekonomi orang tua siswa pada tahun 2019 tergolong rendah. Dimana dari seluruh jumlah siswa terdapat 58 orang siswa tergolong ekonomi rendah.

\section{Tabel 1. Tingkat Status Ekonomi Orang} Tua Siswa

\begin{tabular}{ccc}
\hline No & $\begin{array}{c}\text { Tingkat Status Ekonomi Orang } \\
\text { Tua Siswa }\end{array}$ & Jumlah \\
\hline 1 & Tinggi & 31 orang \\
2 & Rendah & 58 orang \\
\hline
\end{tabular}

Tabel di bawah menunjukkan pekerjaan orang tua siswa bervariasi, sebagian besar orang tua siswa bekerja sebagai nelayan, diikuti petani, pedagang, wiraswasta, kemudian PNS.

Tabel 2. Jenis Pekerjaan Orang Tua Siswa

\begin{tabular}{ccccc}
\hline No & $\begin{array}{c}\text { Pekerjaan Orang } \\
\text { Tua }\end{array}$ & Ayah & Ibu & Jumlah \\
\hline 1 & PNS & 2 & 2 & 4 \\
2 & Pedagang & & 32 & 32 \\
3 & Wiraswasta & 10 & 8 & 18 \\
4 & Ibu Rumah & & 48 & 48 \\
& Tangga & & & \\
5 & Petani & 34 & & 34 \\
6 & Nelayan & 42 & & 42 \\
\hline
\end{tabular}

Berdasarkan data di bawah dapat dijelaskan bahwa siswa yang sekolah di SD Negeri Matabaho dan SD Negeri 7 Langara Kecamatan Wawonii barat mayoritas tergolong menengah kebawah. Karena berdasarkan data dari Badan Pusat Statistik tahun 2019 bahwa masyarakat yang memiliki pendapatan ekonomi dibawah dari Rp. 1.200.000 merupakan masyarakat yang tergolong ekonomi menengah kebawah.

Tabel 3. Penghasilan Orang Tua Siswa

\begin{tabular}{ccccc}
\hline No & $\begin{array}{c}\text { Penghasilan Orang } \\
\text { Tua }\end{array}$ & Ayah & Ibu & Jumlah \\
\hline 1 & Rp 0- 500.000 & 44 & 70 & 114 \\
2 & Rp 550.000- & 22 & 14 & 36 \\
& $\begin{array}{l}700.000 \\
\text { Rp 750.000- }\end{array}$ & 20 & 2 & 22 \\
4 & $\begin{array}{l}1.200 .000 \\
\text { Rp 1.500.000- } \\
5.000 .000\end{array}$ & 4 & 2 & 6 \\
\hline
\end{tabular}

Peneliti melakukan penelitian di SD Negeri Matabaho dan SD Negeri 7 Langara yang terletak di Kecamatan Wawonii Barat Kabupaten Konawe Kepulauan dengan mengambil populasi kelas IV sampai kelas VI sebagai subjek penelitian, untuk mengetahui hubungan status ekonomi orang tua dengan motivasi belajar siswa. Dipilihnya lokasi tersebut karena peneliti menjumpai fenomena orang tua yang anaknya bersekolah di Matabaho dan SD Negeri 7 Langara mayoritas berada pada kategori ekonomi menengah ke bawah.

Mengenai pentingnya penelitian tentang motivasi belajar siswa, banyak hal yang terjadi dalam proses pendidikan di SD Negeri Matabaho dan SD Negeri 7 Langara. Pada umumnya anak-anak usia SD menghabiskan waktu mereka untuk belajar dan bermain, tetapi beda halnya dengan anak-anak yang bersekolah di SD Negeri Matabaho dan SD Negeri 7 Langara. Dimana mereka harus membantu orang tuanya berjualan di pasar, keliling dari desa satu ke desa yang lain untuk berjualan sayur dan ikan, bahkan kadang mereka tidak bersekolah dengan alasan mengasuh adiknya pada saat orang tua mereka mencari nafkah. Sebagaimana dari pengamatan awal yang dilakukan peneliti di SD Negeri Matabaho dan SD Negeri 7 Langara pada tanggal 18 April 2019 terhadap siswa kelas IV sampai kelas VI pada saat jam pelajaran di kelas, dijumpai 
beberapa siswa yang kurang antusias dalam mengikuti pelajaran ditandai dengan siswa yang tidak memperhatikan saat guru menjelaskan mata pelajaran, siswa lebih senang dengan pekerjaannya sendiri dan ada juga sejumlah siswa yang berbincang dengan teman sebangku pada saat jam pelajaran dimulai, serta terlihat juga siswa yang mengantuk dengan bersandar di bagian dinding kelas pada saat proses belajar mengajar berlangsung, tetapi ada juga siswa yang semangat dalam proses belajar mengajar ditandai dengan siswa yang sering bertanya kepada gurunya apabila siswa tersebut tidak paham apa yang dijelaskan oleh gurunya.

Berdasarkan hasil wawancara yang dilakukan peneliti pada dua orang guru pada masing-masing sekolah yaitu SD Negeri Matabaho dan SD Negeri 7 Langara pada tanggal 20 April 2019 peneliti mendapatkan informasi bahwa beberapa siswa tidak semangat dalam belajar, seperti di kelas selalu ribut, tidak mengerjakan PR, bahkan siswa sering mengerjakan PR di sekolah. Tetapi, ada juga siswa yang mengerjakan PR tepat waktu, belajar atas kemauan sendiri, serta suka berlatih mengerjakan soal-soal tanpa diperintah oleh orang tua ataupun gurunya.

Sementara itu, diskusi dengan tiga orang siswa masing-masing sekolah kelas IV - VI, diketahui bahwa ketika sekolah, mereka memiliki kebiasaan malas, ada siswa yang berpendapat bahwa, ketika sekolah yang terpenting adalah berangkat ada anggapan bahwa nilai tidak cukup penting yang terpenting adalah mengikuti kegiatan sekolah dan bisa naik kelas setelah itu lulus. Tetapi, ada juga siswa yang berpendapat bahwa sekolah itu harus naik kelas, kemudian mendapat juara dan bisa lulus dengan nilai yang bagus.

Berdasarkan penelitian sebelumnya yang dilakukan oleh Rahmawati (2010) tentang Hubungan Status Sosial Ekonomi Orang Tua dengan Motivasi Belajar PAI Siswa di SMP Darussalam Ciputat menghasilkan siswa yang orang tuanya mempunyai status sosial ekonomi tinggi (memadai), maka siswa tersebut akan mempunyai motivasi belajar yang tinggi untuk lebih giat belajar. Sedangkan bagi siswa yang orang tuanya mempunyai status sosial ekonomi rendah, maka siswa tersebut akan sulit mendapatkan motivasi belajar tinggi karena adanya kebutuhan lain yang harus dipenuhi. Sedangkan penelitian yang dilakukan oleh Karouw, Opod, \& Sinolungan (2015) tentang hubungan status sosial ekonomi orang tua dengan motivasi belajar pada mahasiswa angkatan 2013 Fakultas Kedokteran Universitas Sam Ratulangi. Menghasilkan tidak ada hubungan antara Status Sosial Ekonomi Orang Tua dengan Motivasi Belajar pada Mahasiswa Angkatan 2013 Fakultas Kedokteran Universitas Sam Ratulangi dengan nilai signifikansi sebesar 0,444 .

Maka dari itu dengan memperhatikan permasalahan dan data yang peneliti peroleh, peneliti kemudian tertarik untuk melakukan penelitian dengan judul "Hubungan Status Ekonomi Orangtua dengan Motivasi Belajar Siswa SD Negeri Matabaho dan SD Negeri 7 Langara Kecamatan Wawonii Barat".

Tujuan dari penelitian ini adalah untuk mengetahui apakah terdapat hubungan antara status ekonomi orang tua dengan motivasi belajar SD Negeri Matabaho dan SD Negeri 7 Langara Kecamatan Wawonii Barat.

Hipotesis dalam penelitian ini yaitu terdapat hubungan antara status ekonomi orang tua dengan motivasi belajar siswa di SD Negeri Matabaho dan SD Negeri 7 Langara kecamatan Wawonii Barat.

\section{Metode Penelitian}

Penelitian ini merupakan penelitian kuantitatif dengan menggunakan desain penelitian korelasional yang terdiri dari status ekonomi orang tua sebagai variabel bebas (X) dan Motivasi belajar sebagai variabel terikat (Y). Populasi dalam penelitian ini adalah siswa SD Negeri Matabaho dan SD Negeri 7 Langara dengan total populasi sebanyak 106 orang 
siswa yang terdiri dari kelas IV sampai dengan kelas VI. Teknik penarikan sampel dalam penelitian ini menggunakan teknik penarikan sampel total Purposive Total Sampling sehingga ditemukan sampel sebanyak 89 orang siswa. Metode penggumpulan data menggunakan skala likers bentuk sikap dan perilaku untuk mengukur status ekonomi orang tua skala dari Musyawarah (2016), yang dimodifikasi oleh peneliti dan juga motivasi belajar skala yang dimodifikasi dari Jannah (2017). Dengan nilai Reliabilitas status ekonomi orang tua sebesar 0,836 serta nilai Validitas sebesar 25 aitem dinyatakan valid dan 5 aitem dinyatakan gugur sedangkan nilai Reliabilitas motivasi belajar 0, 863 serta nilai validitas sebesar 39 dinyatakan valid dan 15 aitem dinyatakan gugur.

Analisis data yang digunakan dalam penelitian ini adalah analisis data deskripstif, yaitu untuk memberikan deskripsi mengenai data dari variabel yang diukur dan analisis data inverensial. Untuk mengetahui apakah data terdistribusi secara normal yakni menggunakan teknik Kolmogrov Smirnov, dan apakah data dalam penelitian ini berhubungan secara linear dengan menggunakan Test For Linearity, serta pengujian hipotesis menggunakan teknik Korelasi Produc Momoent Pearson dengan menggunakan Statistical Product and Service Solution (SPSS) 20.0.

\section{Hasil Penelitian dan Pembahasan}

Berdasarkan uji deskriptif data penelitian di bawah dapat dijadikan dasar dalam pengkategorian sampel penelitian. Tujuan dari kategorisasi ini untuk menempatkan subjek kedalam kelompokkelompok yang berjenjang menurut rangkaian berdasarkan atribut yang diukur (Azwar, 2017).
Tabel 1. Data Deskriptif Penelitian

\begin{tabular}{llllll}
\hline & $N$ & $\begin{array}{l}\text { Xmi } \\
n\end{array}$ & $\begin{array}{l}\text { Xma } \\
x\end{array}$ & $\begin{array}{l}\text { Mea } \\
n\end{array}$ & $\begin{array}{l}\text { Standar } \\
\text { deviasi }\end{array}$ \\
\hline $\begin{array}{l}\text { Status Ekonomi } \\
\text { Orang Tua }\end{array}$ & 89 & 66 & 114 & 91,35 & $\begin{array}{l}12,05 \\
6\end{array}$ \\
Motivasi Belajar & 89 & 76 & 154 & $\begin{array}{l}123,4 \\
2\end{array}$ & $\begin{array}{l}21,50 \\
0\end{array}$
\end{tabular}

Berdasarkan data tabel di bawah, ditemukan bahwa dari 89 subjek terdapat 16 orang yang memiliki status ekonomi orang tua rendah dengan persentase $17,98 \%, 56$ orang dalam kategori sedang dengan persentase $62,92 \%$, dan 17 orang dalam kategori tinggi dengan persentase $19,10 \%$.

Tabel 2. Kategorisasi Status Ekonomi Orang Tua

\begin{tabular}{llll}
\hline Skor & $\begin{array}{l}\text { Jumlah } \\
\text { subjek }\end{array}$ & $\begin{array}{l}\text { Persentase } \\
(\%)\end{array}$ & Kategorisasi \\
\hline$<(79,294)$ & 16 & $17,98 \%$ & Rendah \\
$(79,294) \leq \mathrm{X}$ & 56 & $62,92 \%$ & Sedang \\
$<(103,406)$ & & & \\
$(103,406) \leq \mathrm{X}$ & 17 & $19,10 \%$ & Tinggi \\
& & & \\
Total & 89 & $100 \%$ & \\
\hline
\end{tabular}

Berdasarkan data tabel di bawah, ditemukan bahwa dari 89 subjek terdapat 13 orang yang memiliki motivasi belajar rendah dengan persentase $14,60 \%, 52$ orang dalam kategori sedang dengan persentase $58,42 \%$, dan 24 orang dalam kategori tinggi dengan persentase 26,98\%.

Maka dapat disimpulkan bahwa sebagian besar siswa SD Negeri Matabaho dan SD Negeri 7 Langara Kecamatan Wawonii barat yang menjadi sampel memiliki motivasi belajar dalam kategori yang sedang. 
Tabel 3. Kategorisasi Motivasi Belajar Siswa

\begin{tabular}{llll}
\hline Skor & $\begin{array}{l}\text { Jumlah } \\
\text { subjek }\end{array}$ & $\begin{array}{l}\text { Persentase } \\
(\%)\end{array}$ & Kategorisasi \\
\hline $\mathrm{X}<(101,92)$ & 13 & $14,60 \%$ & Rendah \\
$\begin{array}{l}101,92) \leq \mathrm{X} \\
<(144,92)\end{array}$ & 52 & $58,42 \%$ & Sedang \\
$(144,92) \leq \mathrm{X}$ & 24 & $26,98 \%$ & Tinggi \\
& & & \\
Total & 89 & $100 \%$ & \\
\hline
\end{tabular}

Berdasarkan uji normalitas yang dilakukan dengan menggunakan teknik One-Sample Kolmogrov Smirnov pada SPSS versi 20.0 menunjukkan nilai signifikansi sebesar 0,093. Nilai ini lebih besar dari 0,05. Ini menunjukkan bahwa data variabel status sosial ekonomi orang tua dan variabel motivasi belajar terdistribusi secara normal.

Tabel 4. Uji Normalitas

\begin{tabular}{lll}
\hline \multicolumn{3}{c}{ One-Sample Kolmogorov-Smirnov Test } \\
& Signifikansi & Keterangan \\
\hline Motivasi Belajar & 0,093 & $\mathrm{P} \geq 0,05$ (Normal) \\
Status Ekonomi & 0,093 & $\mathrm{P} \geq 0,05$ (Normal) \\
Orang Tua & & \\
\hline
\end{tabular}

Berdasarkan uji linearitas yang dilakukan dengan menggunakan Test from linearity pada SPSS versi 20.0 menunjukkan nilai signifikansi Deviation From Linearity sebesar 0,668. Nilai ini lebih besar dari 0,05 , ini menunjukkan bahwa data variabel status sosial ekonomi orang tua dan variabel motivasi belajar berhubungan secara linear.

Tabel 5. Uji Linearitas

\begin{tabular}{lll}
\hline Variabel & $\begin{array}{l}\text { Sig. } \\
\text { From Linearity }\end{array}$ & Keviation \\
\hline $\begin{array}{l}\text { Motivasi } \\
\text { Belajar }\end{array}$ & 0,668 & Alat ukur (Linear) \\
$\begin{array}{l}\text { Status } \\
\text { Ekonomi }\end{array}$ & 0,668 & Alat ukur (Linear) \\
Orang Tua & & \\
\hline
\end{tabular}

Hasil data menunjukkan nilai signifikansi 0.510 , nilai ini lebih besar dari 0,05 , sehingga dapat dikatakan bahwa terdapat hubungan yang tidak signifikan antara status ekonomi orang tua dengan motivasi belajar siswa SD Negeri Matabaho dan SD Negeri 7 Langara Kecamatan Wawonii Barat.

Berdasarkan uji statistik nilai koefisien korelasi yang dihasilkan -,071 yang berdasarkan kriteria pedoman koefisien korelasi berada pada kategori sangat rendah, yang berarti tidak ada korelasi antara status ekonomi orang tua dengan motivasi belajar siswa.

Tabel 6. Uji Korelasi

\begin{tabular}{lll}
\hline Variabel & $\begin{array}{l}\text { Korelasi } \\
\text { Pearson }\end{array}$ & Sig. \\
\hline Motivasi Belajar & $-0,71$ & 0,510 \\
Status Ekonomi Orang & $-0,71$ & 0,510 \\
Tua & & \\
\hline
\end{tabular}

Hal ini disebabkan karena banyaknya responden yang berasal dari status ekonomi yang rendah dibandingkan status ekonomi yang tinggi. Hal ini senada dengan pendapat Winkel (1996) bahwa keadaan status ekonomi keluarga yang ekonominya tinggi dapat menciptakan kondisi siswa yang menghambat dalam belajar. Siswa berpikir bahwa untuk apa belajar dengan sungguh-sungguh atau rajin jika semua kebutuhan sudah terpenuhi. Sebaliknya siswa yang berasal dari lingkungan keluarga yang ekonominya rendah biasanya kerap jauh lebih rajin, namun ada juga siswa yang merasa minder bila belajar dengan anak-anak orang kaya.

Penelitian ini memiliki persamaan dengan penelitian yang dilakukan oleh Karouw, Opod, \& Sinolungan (2015) tentang hubungan status sosial ekonomi orang tua dengan motivasi belajar pada mahasiswa angkatan 2013 Fakultas Kedokteran Universitas Sam Ratulangi. Dimana persamaannya yaitu sama-sama tidak memiliki hubungan antara status ekonomi dengan motivasi belajar,

Menurut Prabawa (2014) apabila perekenomian tinggi, lingkungan yang dihadapi individu itu lebih luas, maka dapat mempunyai kesempatan yang luas pula untuk mengembangkan kemampuan dan kecakapannya. Tetapi, jika 
perekonomian orang tua itu rendah, belum tentu juga individu mengalami kesulitan dan tidak akan mendapatkan kesempatan yang luas untuk mengembangkan kemampuan dan kecakapannya.

Hal lain yang peneliti temukan yaitu berbeda dengan penelitian yang dilakukan oleh Rahmawati (2010) dengan judul hubungan status sosial ekonomi orang tua dengan motivasi belajar PAI Siswa SMP Darussalam di Ciputat, dengan nilai koefisien korelasi 0,64 menunjukkan terdapat korelasi yang signifikan antara status sosial ekonomi orang tua dengan motivasi belajar PAI pada siswa. Dimana siswa yang orang tuanya mempunyai status sosial ekonomi yang tinggi (memadai), maka siswa tersebut akan mempunyai motivasi belajar yang tinggi pula untuk lebih giat dalam belajar dan penelitian yang dilakukan oleh Syafitri (2016) dengan judul hubungan status sosial ekonomi terhadap motivasi belajar siswa kelas VI MIN Wonosari tahun ajaran 2015/2016, dengan nilai koefisien korelasi 0,381 menunjukkan terdapat korelasi yang signifikan antara status sosial ekonomi dan motivasi belajar.

Berdasarkan pengkategorian yang telah dilakukan sebelumnya, tingkat hubungan status ekonomi orang tua terhadap motivasi belajar SD Negeri Matabaho dan SD Negeri 7 Langara Kecamatan Wawonii Barat dapat dijelaskan sebagai berikut, terdapat 3 siswa yang memiliki status ekonomi orang tua tinggi, ternyata juga memiliki motivasi belajar yang rendah, sebanyak 7 orang siswa yang memiliki status ekonomi orang tua sedang, juga memiliki motivasi belajar rendah, dan 11 orang siswa yang memiliki status ekonomi orang tua tinggi, juga memiliki motivasi belajar yang sedang. Kemudian 11 orang siswa yang memiliki status ekonomi orang tua rendah, juga memiliki motivasi belajar sedang. Serta 19 orang siswa yang memiliki status ekonomi orang tua sedang, ternyata juga memiliki motivasi belajar tinggi, dan 2 orang siswa yang memiliki status ekonomi orang tua rendah, juga memilki motivasi belajar tinggi.

Data lain ditemukan pada 3 siswa yang memiliki status ekonomi orang tua tinggi, juga memiliki motivasi belajar yang tinggi pula. Sebanyak 30 siswa memiliki status ekonomi orang tua sedang, juga memiliki motivasi belajar yang sedang, dan sebanyak 3 siswa memiliki status ekonomi orang tua rendah juga memiliki motivasi belajar yang rendah. Untuk lebih jelasnya di bawah ini terdapat tabel yang menunjukkan tingkat hubungan status ekonomi orang tua dan motivasi belajar berdasarkan kategorisasi.

Tabel 7. Pengkategorisasian Status Ekonomi Orang Tua dan Motivasi Belajar Siswa

\begin{tabular}{lllll}
\hline $\begin{array}{l}\text { Status Ekonomi } \\
\text { Orang Tua }\end{array}$ & \multicolumn{3}{c}{ Motivasi Belajar } & Total \\
\cline { 2 - 4 } & Tinggi & Sedang & Rendah & \\
Tinggi & 3 & 11 & 3 & 17 \\
Sedang & 19 & 30 & 7 & 56 \\
Rendah & 2 & 11 & 3 & 16 \\
Total & 24 & 52 & 13 & 89 \\
\hline
\end{tabular}

Sehingga berdasarkan uraian di atas dapat disimpulkan bahwa siswa SD Negeri Matabaho dan SD Negeri 7 Langara memiliki motivasi belajar rendah, sedang dan memiliki motivasi belar tinggi. Hal tersebut dapat dilihat dari siswa tidak semangat dalam belajar, seperti di kelas selalu ribut, tidak mengerjakan PR, bahkan siswa sering mengerjakan PR di sekolah. Tetapi, ada juga siswa yang mengerjakan PR tepat waktu, belajar atas kemauan sendiri, serta suka berlatih mengerjakan soal-soal tanpa diperintah oleh orang tua ataupun gurunya.

Berdasarkan tinjauan literatur, peneliti menjumpai beberapa faktor yang dapat menyebabkan variabel status ekonomi orang tua dengan motivasi belajar siswa tidak berhubungan, antara lain pola asuh orang tua. Hal ini dikemukakan oleh Hidayah (2012) bahwa orang tua adalah 
motivator belajar yang penting bagi anak usia sekolah dasar. Sebab orang tua merupakan pendidik pertama dari pengalaman anak-anak. Media sosial, hal ini dikemukakan oleh Hermanto, Iqom, \& Rahmawati (2017) bahwa media sosial merupakan situs dimana seseorang bisa membuka web page pribadi kemudian terhubung dengan teman-teman untuk berbagi informasi dan komunikasi. Penggunaan media sosial sangat mempengaruhi aktivitas seseorang, salah satunya adalah motivasi belajar. Lingkungan pembelajaran, hal ini dikemukakan oleh Amin dan Harianti (2017) dimana lingkungan pembelajaran akan menentukan hasil dan motivasi belajar siswa.

Faktor lain yang ditemukan adalah teman sebaya. Rahmawati (2016) menyatakan bahwa teman sebaya memiliki peranan penting dalam perkembangan pribadi dan sosial anak. Salah satunya yaitu memberikan sumber informasi dan perbandingan dunia di luar keluarga. Sehingga memberikan motivasi tersendiri buat anak dalam proses belajar. Sebagaimana diketahui bahwa motivasi belajar merupakan suatu hal yang sangat dibutuhkan oleh siswa dalam proses belajar. Seperti yang dikemukakan oleh Muhammad (2016) bahwa motivasi dan belajar merupakan dua hal yang tidak dapat dipisahkan, karena didalam kegiatan belajar diperlukan motivasi yang mendukung proses belajar siswa. Sedangkan menurut Oktiani (2017) motivasi belajar berasal dari dalam dan luar. Agar motivasi belajar dapat tumbuh dalam diri siswa, maka diperlukan stimulasi salah satunya adalah guru yang kreatif.

Berdasarkan pendapat di atas dapat disimpulkan bahwa status ekonomi orang tua bukan merupakan faktor utuma yang menyebabkan siswa tidak memiliki motivasi belajar. Sehingga siswa yang memiliki status ekonomi rendah dan tinggi memiliki peluang yang sama dalam hal motivasi belajar.

\section{Kesimpulan}

Berdasarkan hasil penelitian yang telah dilaksanakan, dapat disimpulkan bahwa hipotesis dalam penelitian ini ditolak. Lebih lanjut peneliti menemukan hubungan negatif antara status sosial ekonomi orang tua dengan motivasi belajar. Artinya, semakin tinggi status ekonomi orang tua semakin rendah motivasi belajar.

Kemudian dengan adanya penelitian ini dapat memberikan informasi pada sekolah bahwa tidak ada hubungan status ekonomi orang tua dengan motivasi belajar. Sehingga dapat dijadikan pelajaran kepala sekolah, dan guru-guru untuk memberikan suatu metode pembelajaran yang sesuai dengan kemampuan siswa pada umumnya untuk proses belajar mengajar tanpa melihat kondisi status ekonomi orang tuanya.

\section{Daftar Pustaka}

Amin, S., \& Harianti, R. (2017). Pola asuh orang tua dan lingkungan pembelajaran terhadap motivasi belajar siswa. Jurnal Curricula. 1(2). 20-29.

Azwar. (2017). Metode Penelitian Psikologi. Yogyakarta: Pustaka Pelajar.

Bramanhta, H., \& Yulianto, D. E. (2020). Pengaruh kondisi ekonomi orangtua terhadap motivasi belajar pada siswa Sekolah Dasar. Journal of Islamic Primary Education. 3(1), 46-55.

Fauzia, A., Rosnaningsih, A., \& Azhar, S. (2017). Hubungan antara motivasi belajar dengan minat belajar siswa kelas VI SDN Poris Gagah 05 Kota Tangerang. Jurnal JPSD. 4(2), 4753.

Gebrinna, A., Dahlan, S., \& Andrianto, R. E. (2019). Hubungan status ekonomi dan tingkat pendidikan 
orang tua dengan motivasi belajar siswa. Jurnal Bimbingan Konseling. 7(1), 1-15.

Hidayah, T. S. (2012). Hubungan pola asuh orang tua dengan motivasi belajar siswa keas V MI Negeri Sindutan Temon Kulon progo. Skripsi. Tidak diterbitkan. Universitas Negeri Sunan Kalijaga.

Hermanto, Iqom, B. K. M., \& Rahmawati. N. H. (2017). Hubungan durasi penggunaan media sosial dengan motivasi belajar remaja. Jurnal Keperawatan. 5(2), 77-81.

Jannah, Z. M. (2017). Pengaruh fasilitas belajar dan motivasi belajar terhadap prestasi belajar siswa kelas $\mathrm{V}$ pada mata pelajaran matematika di MI Bustanul Ulum Brudu Sumobito Jombang. Tesis. Tidak diterbitkan. Universitas Islam Negeri Maulana Malik Ibrahim.

Kadir, A., Fauzia, A., Yulianto, E., Baehaki, Kurnianto, R., Rosmianti \& Nu'man, A. (2012). Dasar-dasar Pendidikan. Jakarta: Prenada Media Group.

Karouw, M. R. C., Opod, H., \& Sinolungan, V. S. J. (2015). Hubungan status sosial ekonomi orang tua dengan motivasi belajar pada mahasiswa angkatan 2013 Fakultas Kedokteran Universitas Sam Ratulangi. Jurnal e-Biomedik, 3(1), 467-470.

Kartono. (2006). Peran keluarga memandu anak. Jakarta: CV. Rajawali.

Kompri. (2015). Motivasi pembelajaran perspektif guru dan siswa. Bandung: PT Rosda Karya.
Lilawati, A. (2020). Peran orang tua dalam mendukung kegiatan pembelajaran di rumah pada masa pandemi. Jurnal Pendidikan Anak Usia Dini. 5(1). 549-558.

Muhammad, M. (2016). Pengaruh motivasi dalam pembelajaran. Lantanida Jurnal. 4(2). 87-97.

Musyawarah. (2016). Hubungan minat belajar dan status ekonomi orang tua dengan hasil UN MTS AlIkhlas SOE Kabupaten Timur Tengah Selatan tahun ajaran 2014/2015. Tesis. Tidak diterbitkan. Universitas Pasca Sarjana, Universitas Terbuka Jakarta.

Nurkholis. (2018). Pendidikan dalam upaya memajukan teknologi. Jurnal Kependidikan. 1(1). 24-44.

Oktiani, I. (2017). Kreativitas guru dalam memotivasi belajar peserta didik. Jurnal Pendidikan. 5(2). 216-232.

Prabawa, A. (2014). Pengaruh model pembelajaran $P O E$ terhadap hasil IPA siswa kelas 4 SDN di Desa Ringdikit. Journal Mimbar PGSD Universitas Pendidikan Ganesha Jurusan PGSD, 2(1), 19-32.

Pratiwi, D. E., \& Prasetya, N. E. (2019). Pengaruh status sosial ekonomi dan motivasi belajar terhadap prestasi belajar siswa kelas $\mathrm{V}$ SDN Tambaksari I Surabaya. Jurnal Pendidikan dan Pengajaran Guru Sekolah Dasar. 2(1), 36-40.

Rahmawati, D. (2010). Hubungan status sosial ekonomi orang tua dengan motivasi belajar PAI siswa di SMP darussalam Ciputat. Skripsi. Tidak diterbitkan. Universitas Islam Negeri Syarif Hidayatullah Jakarta. 
Rahmawati, I. (2016). Hubungan interaksi teman sebaya dengan motivasi belajar siswa kelas V Sekolah Dasar Negeri Diyono 10 Malang. Skripsi. Tidak diterbitkan. Universitas Islam Negeri Maulana Malik Ibrahim.

Rizkiana, A. (2014). Pengaruh status sosial ekonomi orang tua, motivasi belajar, disiplin belajar terhadap prestasi belajar pada siswa SMK Barunawati. Jurnal Ekonomi Pendidkan dan Kewirausahaan, 2(2), 186-200.

Sumarna, E., Syafe'i. M \& Marwah, S. S. (2018). Relevansi konsep pendidikan menurut KI Hajar Dewantara dengan pendidikan. Jurnal of Islamic Education. 5(1). 14-26.

Suprihatin, S. (2015). Upaya guru dalam meningkatkan motivasi belajar siswa. Jurnal Pendidikan Ekonomi UM Metro. 3(1), 73-82.

Syafitri, H. M. (2016). Hubungan status sosial ekonomi orang tua terhadap motivasi belajar pada siswa kelas VI MIN Wonosari tahun ajaran 2015/2016. Skripsi. Tidak diterbitkan. Universitas Islam Negeri Sunan Kalijaga Yogyakarta.

Uno, H. B. (2011). Teori motivasi dan pengukurannya, analisis di bidang pendidikan. Jakarta: PT Bumi Aksara.

Utomo, D. S., Adi, W. B \& Sunarto. (2018). Pengaruh status sosial ekonomi orang tua dan motivasi belajar terhadap hasil belajar kognitif kewirausahaan pada siswa kelas XI SMK Kristen 1 Surakarta tahun ajaran 2017/2018. Jurnal Pendidikan Bisnis dan Ekonomi, 4(1), 1-10.

Widodo, J., Ani, M. H., \& Chotimah, N. L. (2017). Pengaruh status sosial ekonomi orang tua terhadap prestasi belajar siswa. Jurnal Ilmiah Ilmu Pendidikan, Ilmu Ekonomi dan Ilmu Sosial. 11(1), 75-80.

Winkel, W.S. (1996). Psikologi pengajaran. Jakarta: Grasindo. 